\title{
Chapter 20 \\ Climate Resiliency and Location-Specific Learnings from Coastal Bangladesh
}

\author{
Sakib Mahmud, A. K. Enamul Haque, and Kolpona De Costa
}

\section{Key Messages}

- From the perspectives of coastal areas of Bangladesh, location-specific learning effects have a strong connection with socially heterogeneous coastal population's climate resiliency efforts in terms of their gradual investments toward stormresistant homes.

- Location-specific learning effects are more evident among the socially heterogeneous coastal households that are located close to government-sponsored embankments and cyclone shelters, nearest vehicular road, primary school, and a natural capital, such as the mangrove forest.

Disclaimer: The presentation of material and details in maps used in this book does not imply the expression of any opinion whatsoever on the part of the Publisher or Author concerning the legal status of any country, area or territory or of its authorities, or concerning the delimitation of its borders. The depiction and use of boundaries, geographic names and related data shown on maps and included in lists, tables, documents, and databases in this book are not warranted to be errorfree nor do they necessarily imply official endorsement or acceptance by the Publisher, Editor(s), or Author(s).

Electronic supplementary material The online version of this chapter (https://doi.org/10.1007/978-981-16-0680-9_20) contains supplementary material, which is available to authorized users.

\section{S. Mahmud ( $\bowtie)$}

School of Business and Economics, University of Wisconsin-Superior, Superior, USA

e-mail: smahmud@uwsuper.edu

\author{
A. K. E. Haque - K. De Costa \\ Department of Economics, East West University, Dhaka, Bangladesh \\ e-mail: akehaque@gmail.com \\ K. De Costa \\ e-mail: kona_bd@yahoo.com
}


- Targeted policies on post-disaster relief and rehabilitation efforts for most vulnerable coastal households living in high storm-risk zones should be supported with policies to ensure access to external finance for home improvements, access to natural capital through extensive mangrove forest coverage along the coastlines, and dissemination of information on best practices to build cost-efficient storm-resistant homes.

\subsection{Introduction}

Climate adaptation and climate risk literature reveals that social heterogeneity plays a big role in determining the measures taken by households against natural disasters (Cutter \& Finch, 2008; Cutter et al., 2013; Haer et al., 2017; Koks et al., 2015; Smith et al., 2006). Households' capacity to adapt and respond to natural hazards is largely a function of their socio-demographic status that is related to their social vulnerability (Cutter et al., 2013; Koks et al., 2015; Smith et al., 2006). Hence, social heterogeneity in terms of differences in social characteristics of households living in high climate risk areas can be considered an important factor in determining the feasibility of climate mitigation and adaptation policies. Given this observation, this chapter explores how social heterogeneity and location-specific learning shapes the adaptation strategies of coastal households in Bangladesh. Findings from our study not only reveal the factors influencing the capacity of coastal households to adapt and respond to major cyclone events but also develop a better understanding of the policy implications on individual and community risk mitigation, and evacuation plans. We hope our findings might lead to adoption of insurance coverage against natural disaster risks, currently non-existent in developing economies and help government shape other policies to support community-based mitigation of climate change.

Coastal areas around the world are experiencing increasing frequency and severity of tropical storm events (Knutson et al., 2013; IPCC, 2014; Vitousek et al., 2017; Walsh et al., 2016). It is expected that the resiliency of vulnerable coastal communities will be severely tested in future (IPCC, 2014, 2019; World Bank, 2011). Governments which act as insurers of last resort against natural disasters in developing countries with weak catastrophe insurance markets also do not have sufficient funds to support climate-resilient programs to protect coastal communities (IPCC, 2014, 2019; World Bank, 2011). Given such constraints, coastal communities are now investing their time and resources on private defensive strategies (IPCC, Mahmud \& Barbier, 2016; World Bank, 2011). However, effectiveness of private defensive strategies, a form of individual and community-based adaptation strategies, might be influenced by a host of factors. They are: (i) publicly sponsored climate-resilience programs, such as embankments and cyclone/storm shelters (Kunreuther et al., 2016; Lewis \& Nickerson, 1989; Mahmud \& Barbier, 2016); (ii) access to a natural capital, such as a mangrove forest (Das, 2021; Mahmud \& Barbier, 2016; Chap. 17 of this volume) and asset ownership (Prowse \& Scott, 2008; Vatsa, 2004); (iii) access to financial and social capital (Adger et al., 2003; Mahmud \& Barbier, 2016); and 
(iv) access to domestic and foreign remittances (Clarke \& Wallsten, 2003; Yang \& Choi, 2007). Our literature review reveals that there are few comprehensive studies that identify the most important factors influencing private adaptation strategies of vulnerable poor coastal communities in developing countries. To fill this research gap, we performed a more inclusive empirical analysis using cross-sectional household survey data collected from twelve villages in three south-western coastal districts of Bangladesh that were exposed to two severe cyclonic storm events: 2007, Cyclone Sidr and 2016, Cyclone Roanu.. ${ }^{1}$ Besides information on household demographics, consumption, and socio-economic information, our household survey data include information on damages inflicted by each storm event, households' perception of their homes being exposed to future storm event, domestic and foreign remittances, access to external finance and non-governmental organizations (NGOs), migration, household loans, and land ownership. In addition, the survey data includes information on household home structure before each storm event (i.e., before 2007, Cyclone Sidr and before 2016, Cyclone Roanu) and during the survey period of OctoberNovember 2016. Our data allowed us to construct an asset index and separate home index before each storm event for every household.

We selected the Bangladesh coastal area for our analysis due to its extreme vulnerability to tropical storm (cyclones) events which are expected to increase in frequency and severity (IPCC, 2014; Rawlani \& Sovacool, 2011; World Bank, 2011), and, also, the authors' familiarity with the terrain. In addition, there is well-documented evidence of indigenous private defensive strategies adopted over generations by the coastal communities of Bangladesh. (Garai, 2017; Hasan et al., 2017; Mahmud \& Barbier, 2016). Examples of individual and community-based adaptation behavior include converting a mud house to a brick house (to resist storm and tide-related erosion of walls and floors), raising both the plinth-height, increasing the number of floors, refurbishing the walls, installation of tube well for water, modernization of toilets, improvement of animal sheds, ponds, the boundary of the house, raising the plinths, etc. ${ }^{2}$

\footnotetext{
${ }^{1}$ Cyclone Sidr, with maximum wind speed of $260 \mathrm{~km} / \mathrm{h}$, is a category 5 cyclone under SaffirSimpson scale (greater than $252 \mathrm{~km} / \mathrm{h}$ ) and a severe cyclonic storm with hurricane intensity (greater than $118 \mathrm{~km} / \mathrm{h}$ ) under the Bangladesh Meteorological Department (BMD) scale. It made landfall in southern coastal districts of Bangladesh in November 15, 2007. The storm caused large-scale evacuations with 3447 deaths and an approximate US $\$ 1.7$ billion damages (GOB, 2008). On the other hand, Cyclone Roanu, with a maximum speed of $110 \mathrm{~km} / \mathrm{hour}$, made landfall in in May 21, 2016, in the same area. Through its early warning and evacuation system, Bangladesh was able to successfully reallocate around two million people. Consequently, the death toll was kept at 26 with one lakh houses were damaged, and about 150,000 families were affected (GOB, 2017).

${ }^{2}$ All these private storm-protection actions are identified and listed based on our field and household surveys. Prior to asking households their private storm-protection actions for home improvement against major storms, our survey questions include whether households perceive their homes to be at risk from flooding and tidal surge from a major storm event. These questions are to confirm that the sole purpose for adopting private storm protection actions by the coastal households is to reduce their risks from storm-inflicted damages to homes and other properties. Compared to households that are located inland and living further away from coast, some of these private actions for home
} 
Using household investments for home improvements, which is an important adaptation mechanism to cope against severe cyclones in coastal areas in developing countries and considering the importance of building climate-resilient communities along the Bangladesh coast, we address the following research questions in our study.

(1) Do government-sponsored climate resilience programs, such as embankments, access to vehicular roads, primary schools in the event of cyclones, and cyclone shelters, have significant influence on household decisions to invest more on private adaptation to reduce damages from a major cyclone (storm) event?

(2) Does asset ownership significantly influence household investment on private defensive strategies against storm-inflicted damages?

(3) Does access to external financing through private and public donations (charities), and non-government organizations (NGOs) play a major role in household defensive expenditures to reduce storm-inflicted damages?

(4) Does total remittance from home and abroad lead to higher private defensive expenditures for households?

(5) Do households living close to a natural forest, such as mangroves, invest less on private defensive strategies against major storm or cyclone events?

These are very timely questions since climate risk vulnerabilities are expected to rise for Bangladesh and other coastal communities around the world (GOB, 2008; IPCC, 2019; World Bank, 2011). By finding patterns of private defensive behavior and its relationship with key identifiers, this study would help establish effective coastal adaptation policies for Bangladesh and other developing nations.

The rest of the paper is organized as follows. Section 20.2 discusses the scope of our research. Section 20.3 reports the results based on our empirical analysis. Section 20.4 outlines conclusions and policy recommendations.

\subsection{Scope of the Study and Social Heterogeneous Nature of the Study Area}

For our study area, we considered Bhola, Barguna, and Patuakhali districts of the Barisal division since the Disaster Management Bureau (DMB) of Bangladesh identified these districts as the zones most affected by frequent cyclones. ${ }^{3}$ From each district, we selected an upazila (sub-district). Our selected upazilas are Monpura from Bhola, Amtoli from Barguna, and Kapara from Patuakhali. After selection of the upazilas, we selected two affected unions (the lowest tier of administration in rural

\footnotetext{
improvement might look similar, but they were merely displaying the non-risk factor of improved social standing from the perspectives of the non-coastal households located in these low-risk areas.

${ }^{3}$ Administratively, Bangladesh has 6 divisions, 64 districts or zilas, 508 upazilas, and 4466 unions (Source: Statistical Pocketbook of Bangladesh, 2019). The term 'union' refers to the lowest administrative unit in the rural areas of Bangladesh. Under the Village Chaukidari Act of 1870, villages were grouped into unions to provide for a system of watches and wards in each village.
} 
Fig. 20.1 Study area along with the tracks of Cyclone Sidr and Cyclone Roanu

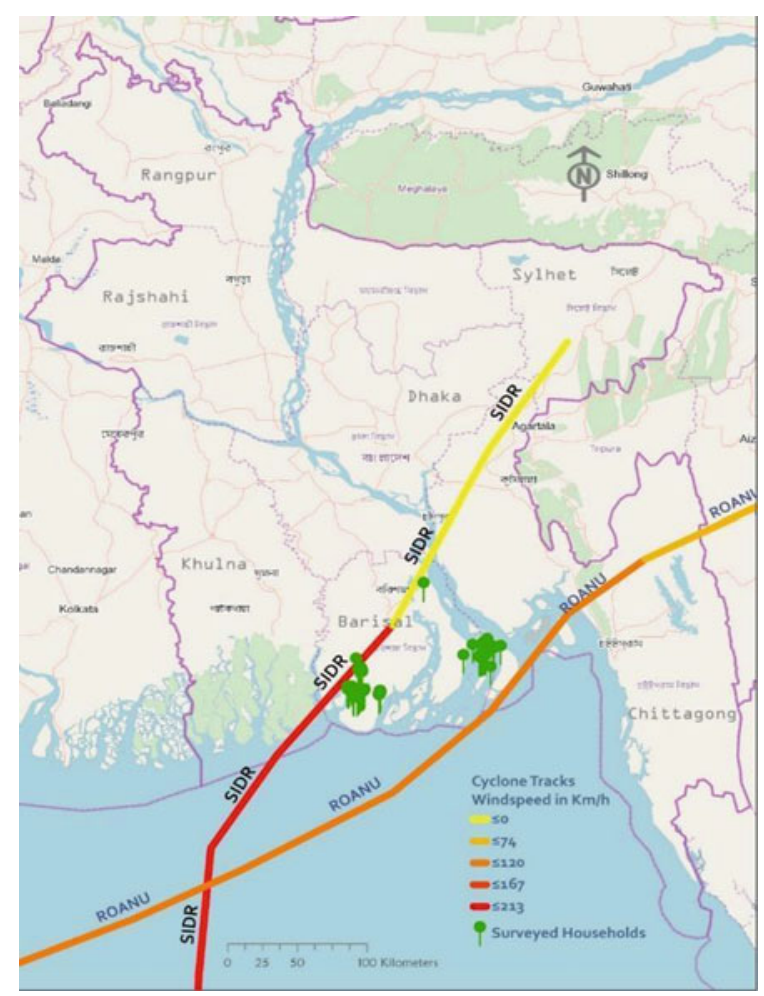

communities) from each upazila based on the available data from the DMB on number of households by exposure to the most recent severe storm events, Cyclone Sidr and Cyclone Roanu, which made landfall on November 15, 2007, and May 23, 2016, respectively. Applying the two-stage sampling methods, we selected 600 households for our survey from twelve villages covering three coastal districts. Figure 20.1 shows our study area along with the tracks of Cyclone Sidr and Cyclone Roanu.

We employed structured questionnaires to conduct interviews as part of our household survey. Prior to the main household survey, a pilot survey was conducted to improve the final version of the questionnaire. Table 20.1 summarizes the distribution of the sample households. For details on demographic and socio-economic characteristics of the respondent households in the survey, please see the supplementary table (Table S20.1).

For adaptation against major storm events, the majority of the households increased the number of floors (25\%), sank new tube wells for water (24\%) and improved their pond areas $(12 \%)$ after Cyclone Sidr. The same adaptation strategies were applied post-Cyclone Roanu. Survey results show that income, savings, and donations were the major sources of funds for adaptation after these two major storm events. On perceptions of public (government-sponsored) adaptation measures 
Table 20.1 Distribution of ample households

\begin{tabular}{l|l|l|l|l}
\hline Districts & Upazila & No. of selected unions & No. of selected villages & $\begin{array}{l}\text { Total number of } \\
\text { households }\end{array}$ \\
\hline Bhola & Monpura & 2 & 4 & 200 \\
\hline Barguna & Amtoli & 2 & 4 & 200 \\
\hline Patuakhali & Kapara & 2 & 4 & 200 \\
\hline Sum total & 6 & 12 & 600 \\
\hline
\end{tabular}

Source Field survey

implemented by the government, around $22 \%$ of the households think building embankments with stone and cement blocks is the most effective strategy.

The next most effective strategy is raising the height of the embankment $(16.46 \%)$ followed by building new cyclone shelters or expanding the existing ones (14\%), building raising floors or heights of the house (13.44\%), and raising plinths (11.55\%). Interestingly, other public adaptation measures, such as building clay embankment $(9.15 \%)$ and afforestation $(7.86 \%)$, did not get much approval from the survey respondents. Our survey data tells that $93.44 \%$ of the households experienced flooding or water logging affecting their houses. For more detailed information, please see the supplementary table (Table S20.2).

Table 20.2 summarizes the sources of funds to support private adaptation measures for home improvements post-Cyclone Sidr and post-Cyclone Roanu. In both cases, we find external finance through public and private donations to be the second most important source of funds followed by household savings.

To understand household investment on different adaptation initiatives, we collected information on adaptation costs for the households based on their location. Table 20.3 shows that houses that are built outside the embankment (31.15\% of the total households surveyed), spent Bangladesh Taka (BDT) 6169 more on average on adaptation costs compared to houses that are built outside the embankment. Interestingly, houses that are protected by the natural forest (11.94\% of the total households surveyed) spent on average BDT 5272 less on adaptation costs than the houses that

Table 20.2 Sources of funds for adaptation

\begin{tabular}{l|l|l|l}
\hline $\begin{array}{l}\text { For adaptation after Cyclone } \\
\text { Sidr (2007) }\end{array}$ & Percentage $(\%)$ & $\begin{array}{l}\text { For adaptation after Cyclone } \\
\text { Roanu (2016) }\end{array}$ & Percentage $(\%)$ \\
\hline Savings & 35.15 & Savings & 46.70 \\
\hline Loan & 16.01 & Loan & 12.83 \\
\hline Donation & 29.02 & Donation & 21.21 \\
\hline Help from friends/ relatives & 6.51 & Help from friends/relatives & 0.71 \\
\hline Sold land / asset & 13.31 & Sold land/ asset & 18.54 \\
\hline Total frequencies $(N=1334)$ & 100 & Total frequencies $(N=561)$ & 100 \\
\hline
\end{tabular}

Source Field survey 
Table 20.3 Differences in adaptation costs based on household location

\begin{tabular}{|c|c|c|c|}
\hline $\begin{array}{l}\text { Location of the } \\
\text { household }\end{array}$ & $\begin{array}{l}\text { Average adaptation } \\
\text { costs (in BDT) }\end{array}$ & $\begin{array}{l}\text { Differences in } \\
\text { adaptation costs (in } \\
\text { BDT) }\end{array}$ & Comments \\
\hline \multicolumn{4}{|c|}{ Protection from major storms due to surrounded by natural forest } \\
\hline $\begin{array}{l}\text { House surrounded by } \\
\text { forest }\end{array}$ & 44,915 & \multirow[t]{2}{*}{$5272^{* * *}$} & \multirow{2}{*}{$\begin{array}{l}\text { Houses surrounded by } \\
\text { forest spent BDT } 5227 \\
\text { less }\end{array}$} \\
\hline $\begin{array}{l}\text { House not surround by } \\
\text { forest }\end{array}$ & 50,187 & & \\
\hline \multicolumn{4}{|c|}{ Protection from major storms due to located inside polder } \\
\hline $\begin{array}{l}\text { House located inside the } \\
\text { polder }\end{array}$ & 47,497 & \multirow[t]{2}{*}{$6169^{* * *}$} & \multirow{2}{*}{$\begin{array}{l}\text { Houses inside the } \\
\text { polder spent BDT } \\
6169 \text { less }\end{array}$} \\
\hline $\begin{array}{l}\text { House located outside } \\
\text { the polder }\end{array}$ & 53,665 & & \\
\hline \multicolumn{4}{|c|}{ Protection from major storms due to located on highland } \\
\hline $\begin{array}{l}\text { House located on the } \\
\text { lowland }\end{array}$ & 48,814 & \multirow[t]{2}{*}{$3227^{*}$} & \multirow{2}{*}{$\begin{array}{l}\text { Houses located on } \\
\text { mid-and- highland } \\
\text { spent BDT } 3227 \text { less }\end{array}$} \\
\hline $\begin{array}{l}\text { House located on the } \\
\text { high land }\end{array}$ & 45,587 & & \\
\hline
\end{tabular}

\section{Source Field survey}

Note Independent samples $t$ test with $N=610$ observations. Statistically significance levels: ${ }^{* * *} 1 \%$, ** $5 \%,{ }^{*} 10 \%$

are not protected by the natural forest. Among the households that are located in lowland areas (33.45\% of the total surveyed), average spending on adaptation costs is BDT 3227 more compared to households located in mid- and highland areas. We also report household perception on their homes being affected by tidal surge from a major cyclone event.

Table 20.4 reveals household perceptions on their homes being affected by flooding and tidal surge. More than $95 \%$ of the total households surveyed felt their homes are at risk of being exposed to flooding and tidal surge from major cyclones.

Table 20.4 Households perception on flooding and tidal surge from major cyclones

\begin{tabular}{l|l|l}
\hline & $\begin{array}{l}\text { Flooding/water logging } \\
\text { Total ‘yes' responses } \\
(\% \text { in brackets out of } 607 \\
\text { valid responses })\end{array}$ & $\begin{array}{l}\text { Tidal surge } \\
\text { Total ‘yes' responses } \\
(\% \text { in brackets out of } \\
607 \text { valid responses })\end{array}$ \\
\hline Study area & $579(95.38 \%)$ & $583(96.05 \%)$ \\
\hline Patuakhali & $194(97.48 \%)$ & $199(100 \%)$ \\
\hline Borguna & $211(100 \%)$ & $198(94 \%)$ \\
\hline Bhola & $174(88.32 \%)$ & $186(4.41 \%)$ \\
\hline
\end{tabular}

Source Field survey 


\subsection{Survey Results and Discussion}

For empirical analysis, our econometric estimations are based on households' response to private storm-protection actions on home improvement after Cyclone Sidr and Cyclone Roanu. All our results are reported as supplementary materials under Tables S20.3, S20.4 and S20.5. Table 20.5 presents the results of ordinary least squares (OLS) regression analyses using the full sample of our survey. Our

Table 20.5 Adaptation costs using OLS estimates

\begin{tabular}{|c|c|c|}
\hline Dependent variable & $\begin{array}{l}\text { Adaptation costs for home } \\
\text { improvement after Cyclone } \\
\text { Sidr }\end{array}$ & $\begin{array}{l}\text { Adaptation costs for home } \\
\text { improvement after Cyclone } \\
\text { Roanu }\end{array}$ \\
\hline Independent variables & (3) & $(6)$ \\
\hline Income (monthly, in log) & $\begin{array}{l}59,684.74 \\
(2.99)^{* * * *}\end{array}$ & $\begin{array}{l}5080.83 \\
(3.86)^{* * *}\end{array}$ \\
\hline $\begin{array}{l}\text { Foreign and domestic remittance } \\
\text { received (in Tk) }\end{array}$ & $\begin{array}{l}-16,499.09 \\
(-0.72)\end{array}$ & $\begin{array}{l}-2725.72 \\
(-1.81)^{* *}\end{array}$ \\
\hline $\begin{array}{l}\text { Home improvement loan (in } \\
\text { Tk.) }\end{array}$ & $\begin{array}{l}-0.0763 \\
(-0.29)\end{array}$ & $\begin{array}{l}-0.0314 \\
(-1.83)^{* *}\end{array}$ \\
\hline Children in household & $\begin{array}{l}-3710.07 \\
(-0.26)\end{array}$ & $\begin{array}{l}-2809.27 \\
(-2.96)^{* * *}\end{array}$ \\
\hline Female in household & $\begin{array}{l}7477.65 \\
(0.88)\end{array}$ & $\begin{array}{l}1648.53 \\
(2.96)^{* * *}\end{array}$ \\
\hline Household earning members & $\begin{array}{l}20,812.88 \\
(1.79)^{* *}\end{array}$ & $\begin{array}{l}-325.51 \\
(-0.43)\end{array}$ \\
\hline $\begin{array}{l}\text { Member of an NGO group }(=1, \\
0 \text { otherwise })\end{array}$ & $\begin{array}{l}39,578.7 \\
(1.46)^{*} \\
\end{array}$ & $\begin{array}{l}863.85 \\
(0.63)\end{array}$ \\
\hline $\begin{array}{l}\text { Access to finance access for } \\
\text { home improvements }(=1,0 \\
\text { otherwise) }\end{array}$ & $\begin{array}{l}28,595.51 \\
(1.02)\end{array}$ & $\begin{array}{l}7790.72 \\
(4.19)^{* * *}\end{array}$ \\
\hline $\begin{array}{l}\text { Home index before Cyclone } \\
\text { Roanu }\end{array}$ & & $\begin{array}{l}-1642.87 \\
(-2.05)^{* *}\end{array}$ \\
\hline $\begin{array}{l}\text { If household located outside the } \\
\text { polder/embankment }(=1,0 \\
\text { otherwise })\end{array}$ & $\begin{array}{l}-5198.07 \\
(-0.17)\end{array}$ & $\begin{array}{l}6475.37 \\
(3.14)^{* * *}\end{array}$ \\
\hline $\begin{array}{l}\text { If household located at low } \\
\text { elevation ( }=1,0 \text { otherwise })\end{array}$ & $\begin{array}{l}-67,774.5 \\
(-1.86)^{* *}\end{array}$ & $\begin{array}{l}4761.47 \\
(1.93)^{* *}\end{array}$ \\
\hline $\begin{array}{l}\text { If household located close to a } \\
\text { natural forest (=1,0 otherwise) }\end{array}$ & $\begin{array}{l}8043.37 \\
(0.34)\end{array}$ & $\begin{array}{l}-5875.38 \\
(-3.80)^{* * *}\end{array}$ \\
\hline Number of obs & 610 & 610 \\
\hline$R$-squared & 0.0925 & 0.2376 \\
\hline Prob $>F$ & 0.0001 & 0.000 \\
\hline
\end{tabular}

$t$ tests are shown in parentheses beneath coefficient estimates. Significance levels: ${ }^{* * *} 1 \%,{ }^{* *} 5 \%$,

${ }^{*} 10 \%$. For more regression estimates, see the supplementary materials 
exact OLS regression specifications are included in the supplementary materials. The household adaptation costs on storm-resistant home improvements are as follows:

The dependent variables are the adaptation costs for home improvements after Cyclone Sidr, and the adaptation costs for improvements for Cyclone Roanu, in Bangladesh Taka (Tk.). To capture the influence of social networks, we included household access to external finance for home improvement and if any household member has connections with at least one non-governmental organization (NGO) that is actively operating within the community. To capture the influence of household psychology behind their adaptation behavior on home improvements, we incorporated household perception of being exposed to damages from future major storm events (cyclones bearing Category 8 or 9 signals), and whether the households experienced loss of assets from 2007, Cyclone Sidr and 2016, Cyclone Roanu events. Lastly, to capture the influence of asset holdings, we created an asset index based on household ownership of farmland, livestock, pond, orchard, poultry, mechanized vehicle and boat, rickshaw or van, shop, rental home, etc. We also created a separate home index before Cyclone Sidr and a similar home index before Cyclone Roanu. These home indices comprised the quality of home structures for wall, roof, and floor materials. A greater value of the home indices indicates that the home structure has improved in terms of its ability to withstand the wrath of a cyclone. We added controls to deal with exogenous sources of variations on households' location preferences, which is the distance of the household from the nearest primary school, vehicular road, embankment, and the cyclone shelter, respectively. For robustness checks of our results, we applied full information maximum likelihood (FIML) of the sample selection model using Heckman (1979).

Results from our empirical analysis using different regression specifications reveal that under a social heterogeneous framework, a household's relative physical location and distance from government-sponsored programs, such as embankments, primary school, and vehicular road are important determinants of household adaptation expenditure for home improvements. In addition, a household's location close to a forest, a natural form of storm-protection, is also an important determinant as it leads to lower adaptation costs for home improvements, and similarly, better-built houses (or higher home index value) had lower impacts. Estimation results from our analysis show that access to external finance through public and private donations positively influences household defensive behavior on converting existing houses to become more storm-resistant. Asset ownership, access to credit, and NGO membership are also influential, but they are not statistically significant in most of the regression specifications using different estimators. Same applies to the remittance variable regarding its insignificant influence on households incurring higher adaptation costs for storm-resistant homes.

Due to data limitations, we acknowledge the fact that there could be some missing variables that might be relevant for future analysis. For example, data on how much money allocated for private adaptation or defensive strategies against major cyclone (storm) events out of total remittance received as well as from different sources of external financing would further improve the analysis. There is also room for improvements by further working on the regression specifications that are considered 
for empirical analysis. Despite the limitations, we think our empirical findings have the potential to contribute to disaster-related literature on household-coping mechanisms and resiliency against climate change-induced developments. The results are consistent across the Cyclone Sidr and the Cyclone Roanu experiences; however, we see a clear recall problem related to Cyclone Sidr data because it had happened about 10 years ago.

\subsection{Conclusion}

Given that the influence of social heterogeneity on coastal households' capacity to adapt and respond to climate change-induced natural disaster risks, our paper examines the major factors that might be influential on private defensive behavior of poor coastal households against major storm events. Our estimates show that households save nearly $\mathrm{t} 6475$ taka $^{4}$ or $\$ 75.2$ dollar in terms of housing improvement costs due to the protection that the forests provide to them. It is 65875 taka or 68.3 USD per household living outside the protection of the embankment. Similarly, higher the home index value, lower is the cost of home improvement after the cyclone.

On policy implications, our empirical results support the influence of governmentsponsored climate resilience programs on vulnerable and poor coastal households' adaptation choices against major cyclone events. Having embankments and ensuring access to nearest vehicular road, primary school, and cyclone shelters, etc., reduce cyclone-inflicted damages to home and other properties. Although these governmentsponsored initiatives allow the coastal households that are living near the public infrastructure to allocate resources in areas other than home improvements, these results also indicate that local and national governments should target their postdisaster relief and rehabilitation efforts for those households that could be identified as most vulnerable to disasters due to their locations away from the infrastructure. Considering the presence of location-specific learning effects, the government can coordinate with the local communities, non-governmental organizations, and donor agencies to impart information and knowledge on best practices in building stormresistant homes at the least possible cost. By encouraging the coastal communities to pursue private defensive strategies or by developing mangroves along the coastline, the government can make its climate-resilient programs including post-disaster relief and rehabilitation programs more effective. Therefore, communities should be pursued to maintain the forests along the coastline to protect them against cyclones. This will reduce their private defensive costs on home improvement.

Since our findings also reveal the importance of access to credit, governments can streamline and simplify regulations for financial institutions and NGOs, so that they can lend credits to households willing to invest in storm-resistant homes and other adaptation strategies against major cyclone events. Although the influence of remittances on household adaptation costs for home improvements turned out to

${ }^{4} 1 \$=$ 七 86 taka (2020) 
be somewhat weak in our estimation results, one cannot rule out its importance in shaping household private defensive behavior in future. Furthermore, our findings indicate that governments should reserve development funds by forming publicprivate partnerships with key stakeholders of the communities. Such development funds could be simultaneously coordinated with policies that encourage long-term adaptive capacities of the socially heterogeneous coastal households to develop more efficient and equitable climate-resilient programs along the Bangladesh coast.

\section{References}

Adger, W. N., Huq, S., Brown, K., Conway, D., \& Hulme, M. (2003). Adaptation to climate change in the developing world. Progress in Development Studies, 3(3), 179-195.

Adida, C. L., \& Girod, D. M. (2011). Do migrants improve their hometowns? Remittances and access to public services in Mexico, 1995-2000. Comparative Political Studies, 44(1), 3-27.

Clarke, G. R., \& Wallsten, S. (2003, January). Do remittances act like insurance? Evidence from a natural disaster in Jamaica. Development Research Group, the World Bank.

Cutter, S. L., Emrich, C. T., Morath, D. P., \& Dunning, C. M. (2013). Integrating social vulnerability into federal flood risk management planning. Journal of Flood Risk Management, 6(4), 332-344.

Cutter, S. L., \& Finch, C. (2008). Temporal and spatial changes in social vulnerability to natural hazards. Proceedings of the National Academy of Sciences, 105(7), 2301-2306.

Das, S. (2021). Valuing the role of mangroves in storm damage reduction in coastal areas of Odisha. In A. K. E. Haque, P. Mukhopadhyay, M. Nepal, \& M. R. Shammin (Eds.), Climate change and community resilience: Insights from South Asia. Springer.

Garai, J. (2017). Qualitative analysis of coping strategies of cyclone disaster in coastal area of Bangladesh. Natural Hazards, 85(1), 425-435.

Government of the People's Republic of Bangladesh. (2008), Super Cyclone Sidr 2007: Impacts and strategies for interventions, a report prepared by the Ministry of Food and Disaster Management, Bangladesh Secretariat.

Government of the People's Republic of Bangladesh. (2017). Report on Cyclone 'Roanu,' a report prepared by the Bangladesh Meteorological Department (BMD).

Haer, T., Botzen, W. W., de Moel, H., \& Aerts, J. C. (2017). Integrating household risk mitigation behavior in flood risk analysis: An agent-based model approach. Risk Analysis, 37(10), 19771992.

Hasan, I., Majumder, M. S. I., Islam, M. K., Rahman, M. M., Hawlader, N. H., \& Sultana, I. (2017). Assessment of community capacities against cyclone hazard to ensure resilience in South central coastal belt of Bangladesh. International Journal of Ecological Science and Environmental Engineering, 4(1), 1-14.

Heckman, J. J. (1979). Sample selection bias as a specification error. Econometrica: Journal of the Econometric Society, 153-161.

Intergovernmental Panel on Climate Change (IPCC). (2014). Climate change 2014: Impacts, adaptation, and vulnerability, fifth assessment report (AR5) (p. 1132). Cambridge University Press.

Intergovernmental Panel on Climate Change (IPCC). (2019). In V. Masson-Delmotte, P. Zhai, H.-O. Pörtner, D. Roberts, J. Skea, P. R. Shukla, A. Pirani, W. Moufouma-Okia, C. Péan, R. Pidcock, S. Connors, J. B. R. Matthews, Y. Chen, X. Zhou, M. I. Gomis, E. Lonnoy, T. Maycock, M. Tignor, T. Waterfield (Eds.), Global warming of $1.5^{\circ} \mathrm{C}$. An IPCC special report.

Koks, E. E., Jongman, B., Husby, T. G., \& Botzen, W. (2015). Combining hazard, exposure and social vulnerability to provide lessons for flood risk management. Environmental Science \& Policy, 47, 42-52. 
Knutson, T. R., Sirutis, J. J., Vecchi, G. A., Garner, S., Zhao, M., Kim, H. S., Bender, M., Tuleya, R. E., Held, I. M., \& Villarini, G. (2013). Dynamical downscaling projections of twenty-first-century Atlantic hurricane activity: CMIP3 and CMIP5 model-based scenarios. Journal of Climate, 26(17), 6591-6617.

Kunreuther, H., \& Pauly, M. (2004). Neglecting disaster: Why don't people insure against large losses? Journal of Risk and Uncertainty, 28(1), 5-21.

Kunreuther, H., Michel-Kerjan, E., \& Tonn, G. (2016, December). Insurance, economic incentives and other policy tools for strengthening critical infrastructure resilience: 20 proposals for action. A study conducted through the Center for Risk Management and Decision Processes, The Wharton School, University of Pennsylvania.

Lewis, T., \& Nickerson, D. (1989). Self-insurance against natural disasters. Journal of Environmental Economics and Management, 16(3), 209-223.

Mahmud, S., \& Barbier, E. B. (2016). Are private defensive expenditures against storm damages affected by public programs and natural barriers? Evidence from the coastal areas of Bangladesh. Environment and Development Economics, 21(6), 767-788.

National Oceanic and Atmospheric Administration. (NOAA, 2019). What is a hurricane, typhoon, or tropical cyclone? Hurricane Research Division. http://www.aoml.noaa.gov/hrd/

Paul, S. K., \& Routray, J. K. (2011). Household response to cyclone and induced surge in coastal Bangladesh: Coping strategies and explanatory variables. Natural Hazards, 57(2), 477-499.

Prowse, M., \& Scott, L. (2008). Assets and adaptation: An emerging debate. Institute of Development Studies (IDS) Bulletin, 39(4), 42-52.

Rawlani, A. K., \& Sovacool, B. K. (2011). Building responsiveness to climate change through community-based adaptation in Bangladesh. Mitigation and Adaptation Strategies for Global Change, 16(8), 845-863.

Roy, A. K. D., \& Gow, J. (2015). Attitudes towards current and alternative management of the Sundarbans Mangrove Forest, Bangladesh to achieve sustainability. Journal of Environmental Planning and Management, 58(2), 213-228.

Smith, V. K., Carbone, J. C., Pope, J. C., Hallstrom, D. G., \& Darden, M. E. (2006). Adjusting to natural disasters. Journal of Risk and Uncertainty, 33(1-2), 37-54.

Statistical Pocketbook of Bangladesh. (2019).

Stock, J. H., Wright, J. H., \& Yogo, M. (2002). A survey of weak instruments and weak identification in generalized method of moments. Journal of Business and Economic Statistics, 20(4), 518-529.

Vatsa, K. S. (2004). Risk, vulnerability, and asset-based approach to disaster risk management. International Journal of Sociology and Social Policy, 24(10/11), 1-48.

Vitousek, S., Barnard, P. L., Fletcher, C. H., Frazer, N., Erikson, L., \& Storlazzi, C. D. (2017). Doubling of coastal flooding frequency within decades due to sea-level rise. Scientific Reports, 7(1), 1399.

Walsh, K. J., McBride, J. L., Klotzbach, P. J., Balachandran, S., Camargo, S. J., Holland, G., Knutson, T. R., Kossin, J. P., Lee, T. C., Sobel, A., \& Sugi, M. (2016). Tropical cyclones and climate change. Wiley Interdisciplinary Reviews: Climate Change, 7(1), 65-89.

World Bank (2011, April). Vulnerability, risk reduction, and adaptation to climate change: Bangladesh. Climate Risk and Adaptation Country Profile.

World Bank. (2018, April). Migration and remittances: Recent developments and outlook, special topic: Transit migration. Migration and Development Brief, 29.

Yang, D., \& Choi, H. (2007). Are remittances insurance? Evidence from rainfall shocks in the Philippines. The World Bank Economic Review, 21(2), 219-248. 
Open Access This chapter is licensed under the terms of the Creative Commons AttributionNonCommercial-NoDerivatives 4.0 International License (http://creativecommons.org/licenses/bync-nd/4.0/), which permits any noncommercial use, sharing, distribution and reproduction in any medium or format, as long as you give appropriate credit to the original author(s) and the source, provide a link to the Creative Commons licence and indicate if you modified the licensed material. You do not have permission under this licence to share adapted material derived from this chapter or parts of it.

The images or other third party material in this chapter are included in the chapter's Creative Commons licence, unless indicated otherwise in a credit line to the material. If material is not included in the chapter's Creative Commons licence and your intended use is not permitted by statutory regulation or exceeds the permitted use, you will need to obtain permission directly from the copyright holder.

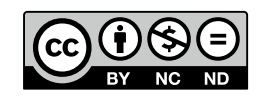

